This item was submitted to Loughborough's Research Repository by the author.

Items in Figshare are protected by copyright, with all rights reserved, unless otherwise indicated.

\title{
Advanced producer service firms as strategic networks, global cities as strategic places
}

PLEASE CITE THE PUBLISHED VERSION

http://dx.doi.org/10.1111/ecge.12040

\section{PUBLISHER}

Wiley / @ Clark University

VERSION

AM (Accepted Manuscript)

\section{PUBLISHER STATEMENT}

This work is made available according to the conditions of the Creative Commons Attribution-NonCommercialNoDerivatives 4.0 International (CC BY-NC-ND 4.0) licence. Full details of this licence are available at: https://creativecommons.org/licenses/by-nc-nd/4.0/

\section{LICENCE}

CC BY-NC-ND 4.0

\section{REPOSITORY RECORD}

Taylor, Peter J., Ben Derudder, James R. Faulconbridge, Michael Hoyler, and Pengfei Ni. 2019. "Advanced Producer Service Firms as Strategic Networks, Global Cities as Strategic Places". figshare. https://hdl.handle.net/2134/15785. 


\section{Advanced Producer Service Firms as Strategic Networks, Global Cities as Strategic Places}

\section{Peter J. Taylor*}

Faculty of Engineering and Environment, Northumbria University, Newcastle upon Tyne, NE1 8SP, UK

crogfam@yahoo.com

\section{Ben Derudder}

School of Geography and Environmental Science, Monash University

VIC3800 Clayton, Australia and

Department of Geography, Ghent University, Ghent, Belgium

ben.derudder@ugent.be

\section{James Faulconbridge}

Department of Organisation, Work and Technology, Lancaster University Management School, Lancaster University, Lancaster, LA1 4YX, UK j.faulconbridge@lancaster.ac.uk

\section{Michael Hoyler}

Department of Geography, Loughborough University, Loughborough, LE11 3TU, UK m.hoyler@lboro.ac.uk

\section{Pengfei Ni}

Chinese Academy of Social Sciences, Beijing, China ni_pengfei@163.com

\footnotetext{
* Corresponding author
} 


\begin{abstract}
Sassen's identification of global cities as 'strategic places' is explored through world city network analysis. This involves searching out advanced producer service (APS) firms that constitute 'strategic networks', from whose activities strategic places can be defined. Twenty-five out of 175 APS firms are found to be strategic, and from their office networks, 45 cities out of 526 are designated as strategic places. A measure of 'strategicness' of cities is devised, and individual findings from this are discussed by drawing on existing literature about how APS firms use specific cities. A key finding shows that New York and London have different levels of strategicness, and this is related to the former's innovation prowess and the latter's role in global consumption of services. Other cases of strategicness discussed in terms of the balance between production and consumption of APSs are Beijing, Hong Kong and Shanghai; Palo Alto; Mexico City; Johannesburg; and Dubai and Frankfurt.
\end{abstract}

\title{
Key words
}

Advanced producer services, global cities, London, New York, strategic places, world city network 


\section{Introduction}

In her classic The Global City Sassen (1991, 3-4) identified, as her 'point of departure', processes of globalization that had 'created a new strategic role for major cities' resulting in a 'new type of city' that 'is the global city'. In her subsequent textbook on the subject, she distinguished global cities as one of three types of 'strategic places' (Sassen 1994, 18) - later extended to four (Sassen 2006, 31) - but her discussion makes clear that it is global cities that are by far the most important strategic places in economic globalization. The prime purpose of this article is to investigate cities as strategic places in contemporary globalization using the methodology developed as world city network analysis (Taylor 2001, 2004; Taylor et al. 2011). This approach deals with many more cities than Sassen considers: here we ask the question, which of these numerous cities can be reasonably identified as strategic places? We deploy world city network analysis findings to answer this question quantitatively so that amongst the cities thus identified we can measure degrees of 'strategicness'. From this we explore different ways in which cities are being strategic, drawing on the literature dealing with selected individual cities.

We treat the concept of strategic places as a specific expression of Sheppard's (2002) geographic positionality within globalization. One of the examples he draws on in his broad discussion of positionality is the 'status' of cities being defined 'by their position within transnational networks' so that 'one can see that the role and trajectory of such cities is bound up with their positionality' (Sheppard, 2002, 324). In arguing that '[o]ur understanding of the spatiality of globalization will be impoverished ... if positionality is neglected' (Sheppard, 2002, 319), Sheppard lists several advantages of this approach, two of which are particularly relevant to our study of strategic places. First, there is the matter of mutuality across networks: the role of the nonlocal in constituting all local places whatever the scale of definition - the conditions for change depend on 'direct interactions with distant places' and not just 'local initiative' (Sheppard, 2002, 319). Second, this same mutuality, which is the essence of network building, can lead researchers away from considering the 'unequal power relations' 
(Sheppard, 2002, 319) that also inhabit networks - all nodes are equal but some are more equal (strategic) than others. This fits neatly with our world city network analysis where it is advanced producer service (APS) firms that are the global network-makers, and it is their urban agglomeration that creates Sassen's global cities. Thus, what is strategic has to be treated from two directions. From the perspective of cities, there are key firms that operate as strategic networks, which cities need to be part of; but equally, from the perspective of firms, there are key cities that are strategic places, where firms have to be. Thus, our argument will bring together Castells' (1996) spaces of flows and spaces of places into a single analysis and interpretation.

We build this analysis and interpretation on the foundations provided by literatures documenting the internationalization of advanced producer service firms such as accounting, advertising, architecture, finance, and law (Bagchi-Sen and Sen 1997; Bryson, Daniels, and Warf 2004; Daniels 1993; Faulconbridge, Hall, and Beaverstock 2008; Jones 2002). This literature details the way firms' policies target particular city spaces as part of efforts to construct coordination capabilities that support both markets exploitation/development and innovation priorities. As such, strategic cities are the sites through which APS firms can both deploy but also develop their core competencies; this mutual relationship being at the heart of agglomeration and localization processes that define the clusterlike economies of world cities (Bathelt, Malmberg, and Maskell 2004; Cook et al. 2007; Faulconbridge et al. 2011). By connecting questions of city strategicness to the location policies of internationalizing APS firms, we do not, however, aspire to match the subtle and nuanced treatment of positionality that Sheppard achieves, but we do attempt to provide a distinct empirical contribution to the discussion based on the foundations of the literature on the internationalization policies of APS firms: a strongly-evidenced, theoretically-sound set of results that do add something new to understanding cities in globalization. Our argument proceeds in seven parts: (1) we present the basic model that we use, which specifies contemporary intercity relations as an interlocking network; (2) we outline the connections between the location policies of internationalizing APS firms and the production of strategic city places; (3) we describe the data 
required to operationalize the model by creating a service values matrix showing how firms use cities, and initial forms of analyses from these data are described for both firms and cities; (4) specific findings for 2010 data are presented describing city-dyad contrasts and globalization strategies of firms; (5) strategic networks are derived from the globalization strategies, and these are employed to identify strategic places; (6) the strategicness of cities is derived by relating strategic network positions to cities' encompassing global network positions; and (7) we interpret our findings in relation to what the literature says about a number of specific cities we have found to be strategic places. What we thus add to the world city network literature is a comprehensive assessment of cities in this category. Our most notable finding concerns London and New York. These two cities dominate world city rankings and are often functionally linked together as 'NYLON'. Not surprisingly, both figure as strategic places in this study, but we are able to separate them in terms of 'strategicness': we will disentangle NYLON within the overall framework of the world city network.

\section{APS Internationalization through Strategic Cities}

Since the seminal work on the role of APSs in the global economy (Beyers 1992; Daniels 1993, 1995; Enderwick 1989), debates about the strategic role of cities have been at the forefront of concerns. Originally centered around questions about why APS firms cluster in cities, and spurning extensive analysis of the way city economies function using agglomeration and localization logics and their explanations of markets and innovation processes, respectively (Pryke 1994; Grabher 2001; Cook et al. 2007; Faulconbridge et al., 2011), this literature has developed in the past decade since studies of the varying roles cities play in firms' strategies have come to the fore (Beaverstock 2007; Faulconbridge et al. 2007, 2008, 2011; Jones 2002; McNeill 2008; Warf 2001). In this regard, BagchiSen and Sen (1997) were ahead of their time when they deployed Dunning and Norman's (1983) eclectic paradigm to analyse the location advantages for APS of different cities. In this work, the 'size and character of the market; regulation of markets; ... and the location of human (skilled labor) and physical assets' were 
identified as core factors influencing where internationalizing APS chose to establish foreign outposts (Bagchi-Sen and Sen 1997, 1158). However, even at this early stage of research, it was noted that 'sector differentiation in terms of internationalization strategies' (Bagchi-Sen and Sen 1997, 1171) was crucial, accounting and advertising being compared and contrasted by Bagchi-Sen and Sen (1997).

Further inspired by calls to open the black box used to represent firms and their strategies in studies of corporations driving economic globalization (Taylor and Asheim 2001; Yeung 2005), the most recent research on APS internationalization, therefore, seeks to identify (1) groups of firms that share common strategic objectives and (2) the differing role of cities in fulfilling these objectives. In relation to issue (1), it is possible to distinguish between what might be called the ubiquitous presence versus the strategic presence approach. The former, most commonly adopted by the Big Four accounting firms (Beaverstock 1996), major financial institutions (Wójcik 2011) and hybrid producer-consumer services, such as temporary staffing agencies (Coe, Johns, and Ward 2007), involves maintaining a presence in as many cities as possible so as to allow revenue maximization through the servicing of local clients' needs. The latter, associated more with advertising (Faulconbridge et al. 2011), architecture (McNeill 2008), and law firms (Faulconbridge 2008), is driven by a desire to locate offices in the most strategically important places, strategic importance being defined in terms of both the global influence and connectedness of markets and the extent to which work in these places is cutting edge in terms of innovation and thus global profile. Similar variations in strategy are also noted by Goerzen, Asmussen, and Nielsen (2013) in their analysis of the location strategies of Japanese multinationals (including but not limited to APS), with only certain firms prioritizing location in strategic world cities.

Connected to debates about internationalization strategy and the more or less strategic role of different places are also questions about the organizational form of APS. For instance, Faulconbridge et al. (2008) synthesize a range of research on APS and apply it to the case of executive search to reveal that depending on 
the strategic importance of a city, alongside regulatory constraints and issues of institutional distance, internationalization may involve: owned offices (traditional foreign direct investment); the establishment of networks (collaboration with local independent APS rather than direct investment); or a hybrid of the two former approaches (investment in already existing local APS who retain some autonomy but become tightly integrated into global corporate networks). While there is some variability, particularly when regulatory barriers restrict the activities of foreign companies in a market as has been the case in India and China for many APS, owned strategies tend to be associated with the most strategically important sites, while networks are used to provide presence when needed in markets that are uncertain in terms of regulatory barriers, stability, or strategic importance. Hybrids allowed midranking city nodes, which are integrated into global economic flows but in less strategic ways, to be effectively served. The example of the executive search firm Korn/Ferry given by Faulconbridge et al. (2008) is illustrative of such connections between organizational form and the strategicness of a city. Owned offices dominate the firm's internationalization strategy, which involves presence in a total of over 70 cities. However, the owned approach is restricted to the most strategic locations such as London, New York, Frankfurt etc. Hybrid forms are used in locations that have less strategic importance, for instance in Mexico City and Monterey, while networks allow a flag to be planted in locations of potential future importance (e.g., Johannesburg) or where a token presence is required but markets are limited (e.g., Auckland).

The APS literature reveals, then, two important insights relevant to the analysis and interpretation of the way cities do or do not become strategic places in the world city network created by APS firms. First, it shows that not all APS firms have the same significance when presence or absence is being used as a proxy of strategicness. The ubiquitous presence strategy means that sectors, such as accounting and finance, potentially maintain a presence in both more and less strategic cities. Hence, we expect most firms in these sectors not to be evident in measures of strategicness. Meanwhile, firms in other sectors that adopt a strategic presence approach will likely be more conspicuous in analyses seeking 
proxies for city strategicness. Second, the APS literature also reveals that while a firm may have tens or hundreds of offices, not all of these offices share an equal level of strategic importance. Variations in strategicness may be reflected in the organizational form used to manage presence but also in other characteristics such as size and staffing. With these insights in mind, the remainder of the article considers how such understandings of variations in the strategic role of cities in APS internationalization might be both captured in world city network analysis methodologies and used to understand the urban spatial architecture of currentday global capitalism.

\section{Basic Model: Interlocking Network Specification}

To deploy the insights gained from the APS literature, it is important to consider their implications for the assumptions in the interlocking network model used in world city network analysis. To do this, we begin by briefly reprising the model's key premises. Our first premise is that cities are formed through commercial relations with other cities (Jacobs 1969), and that these intercity relations compose networks (Taylor, Hoyler, and Verbruggen 2010). As the products of commerce, generic city networks are specified as interlocking networks. This type of network has an unusual formation in that it operates through three levels instead of two. As well as the net and node levels common to all networks, it has a third 'sub-nodal' level. This is its vital property for understanding commercial city networks because it is at the sub-nodal level that we find the agents of the networking process: connections between a firm's offices in different cities are the basis of network making. In identifying these agents we avoid reifying cities as economic agents: it is firms that create city networks by their everyday work through multiple locations. Therefore, city networks encompass the net level at the scale of the economy the cities operate in, the node level as cities, and a subnodal level as multilocation firms. In the specific case of the contemporary world city network, these are the global economy; important cities across the world including Sassen's global cities; and leading APS firms (Taylor 2001). 
The choice of specifying APS firms as the economic agents making the world city network derives directly from Sassen's (1991) identification of this economic sector as a key creator of her global cities. This occurs in two ways. First, global cities through their 'control and command functions' house corporate headquarters and agencies of government that provide the main market for APSs. Second, it is these cities that are the production centers for APSs, the places where product and process innovations keep growing this cutting edge economic sector. This consumption/production dual character of global cities will have a central role in interpreting the strategic places we identify below. However, we depart from Sassen's use of APSs to identify a small subset of cities as 'global' and instead recognize that APSs are much more widespread than her discussion implies. We define a world city network based upon the activities of APS firms that encompass several hundred cities across the world. This reflects the fact that economic globalization is an all-encompassing process; there are no 'unglobal cities', just variations in the form and intensity of global processes across different cities based largely on a city's historical trajectory and contemporary positionality. Thus, we specify the world city network in terms of the worldwide office networks of leading APS firms.

The world city network is formally specified in Taylor (2001); here we provide the basic outline. The network is represented by a city-by-firm matrix $\mathbf{V}_{i j}$, where $\mathrm{v}_{i, j}$ is the 'service value' of city $i$ to firm $j$. This service value is a standardized measure of the importance of a city to a firm's office network, which depends on the size and functions of a firm's office(s) in a city.

The intercity connectivity between two cities $a$ and $i\left(\mathrm{ICC}_{a-i}\right)$ is defined as ${ }^{1}$

\footnotetext{
1 It is in principle possible to generate two different networks based on the data measuring the presence of firms in cities: a firm-to-firm network and a city-to-city network (Neal 2008; Liu and Derudder, 2012). As our interest is primarily in identifying well-connected cities through firms' location strategies, our focus here - as in most world city network analyses - is on the city networks.
} 


$$
\operatorname{ICC}_{a-i}=\sum \mathrm{v}_{a, j} \cdot \mathrm{v}_{i, j} \quad(\text { where } a \neq i)
$$

This provides a measure of the potential work flows, transfers of information and knowledge, between pairs of cities. The assumption behind conceiving the product of service values as a surrogate for actual flows between cities $a$ and $i$ for firm $j$ is that the more important the office, the more links there will be with other offices in a firm's network. In other words, we are using a simple interaction relation as our measure of connectivity: two cities housing large offices will generate more intercity work flows between them than two cities each with small offices.

Typically in world city network analysis, these intercity connectivities are aggregated for each city, and the totals are interpreted as the global network connectivity of a city (GNC), indicating a city's overall importance within the network:

$$
\mathrm{GNC}_{a}=\sum \operatorname{ICC}_{a-i} \quad(\text { where } a \neq i)
$$

This has been the main measure derived from the model and can be interpreted as how well a city is integrated into the world city network, and hence its 'global status'.

\section{Basic Data: Filling the Service Values Matrix}

To operationalize this model requires assessment of firms' office networks to empirically construct a city-by-firm matrix $\mathbf{V}_{i j}$ of service values. The data required for this exercise are readily available on firms' websites where they promote their 'global' status as a means of both impressing clients in a competitive services market and recruiting graduates in a competitive jobs market. However, this source, plus supplementary information as available, produces different levels and types of information for every firm. Thus for each firm, the data have to be converted by using a simple coding system to enable 
cross-firm comparison for analysis. We use a coding from 0 to 5 , whereby in the service values $v_{i, j}, 0$ indicates a city where firm $j$ has no presence and 5 is firm $j$ 's headquarter city. Codes 1 to 4 are then allocated as follows: a typical office of firm j scores a city 2; there must be something deficient to lower the score to 1 , and something extra for it to rise above 2 . For the latter, an especially large office scores 3, an office with extracity jurisdictions (e.g., regional HQ) scores 4. Each firm is assessed individually to decide on boundary decisions away from 2 . With $n$ firms and $m$ cities, such data collection creates an $n$ firms $\mathrm{x} m$ cities array of service values, the basic matrix for interlocking network analysis. Each column of the matrix shows a firm's location strategy as a string of integers from 0 to 5 across $m$ cities; each row shows a city's service mix as a string from 0 to 5 across $n$ firms.

In 2010, we assessed the office networks of 175 firms across 526 cities. The former consisted of 75 financial services firms and 25 each of accounting, advertising, law, and management consulting firms. Firms were chosen using trade information that ranked the firms by size, based on the latest information available (e.g., on turnover). Cities were chosen on the basis of previous experience in this work (315 cities used in earlier data collections) plus all other cities with a population of more than 2 million, all other capital cities of countries with a population over 1 million, and all other cities housing the headquarters of one of our 175 firms. These are arbitrary rules of inclusion, but the aim was to include more cities than necessary (526 in all) so as not to exclude any potentially relevant cities in what is a very dynamic process of world city network formation. The end result is a 175 firms x 526 cities matrix for 2010 providing 92,050 service values for analysis.

\section{Specific Findings for 2010: City-dyad Analysis and Globalization Strategies}

There are two findings from analyses of these 2010 data that have stimulated the current article. One concerns a city-dyad analysis that focuses on the intercity connectivities as defined in equation (1) (Taylor et al. 2013a). The other is a 
principal components analysis of the service values matrix treating firms' location strategies as the input, using 175 variables (Taylor et al. 2013b). For full details of these analyses, readers are referred to the original papers as noted; here we highlight specific findings that will directly feed into how we understand strategic networks and strategic places in subsequent analysis.

In any city-dyad analysis of a large matrix such as ours, there are myriad pairs of cities whose intercity connectivities can be computed as given in equation (1). The initial way of dealing with this surfeit of results is to concentrate on just the largest connectivities: in this case, only the leading 40 city-dyad connectivities are considered. In Table 1 the number of times each of the top 20 cities, as defined by global network connectivity (equation (2)), features in the leading intercity connectivities is listed. For instance, New York appears in more top 40 city-dyads than any other city - 10 times in all. Because global network connectivity is composed of intercity connectivities (equation (2)), there will be a broad relation between overall global network connectivity and the number of leading city-dyads a city belongs to. For instance, it can be seen that there are seven out of these 20 cities that do not feature at all in the leading city-dyads by intercity connectivities, and these are generally found in the lower ranks of global network connectivity in Table 1. But this relation is far from being definitive. Dubai has no partners in top 40 city-dyads despite being ranked ninth for global network connectivity. In stark contrast, Frankfurt, ranked a lowly nineteenth for global network connectivity, is a member of seven such citydyads, which puts it only just behind Hong Kong, Singapore, and Shanghai. What can this mean?

In such circumstances, it is often the exceptions to the rule that are particularly informative, and this is what makes the Dubai/Frankfurt comparison so intriguing. A city's global network connectivity is an aggregate measure that tells us nothing about the specific intercity connections that constitute it: how many connections it is composed of (i.e., the number of other cities it shares firms with), which cities it is more strongly connected to, and where it is relatively weakly connected. Thus, what appears to be happening with Dubai's global 
network connectivity is that it is composed of a relatively dispersed pattern of intercity connectivities featuring more less-important cities than expected for its global network connectivity ranking. Frankfurt, on the other hand, tends to have a more concentrated pattern of intercity connections constituting its global network connectivity, particularly featuring other major cities. Our preliminary interpretation is to link this to these cities' - in Sheppard's (2002) terms positionalities in the world city network: Frankfurt has a more strategic position within the world city network than Dubai, despite the fact that the latter is more generally integrated into the network. It was this train of thought that stimulated us to consider how we could extrapolate from this particular finding and measure the strategicness of cities more generally. To go down this research path requires us to examine the network-makers, the firms whose office networks lie behind the Dubai/Frankfurt contrast and indeed other discrepancies in the relation between global network connectivity and membership in the top 40 city-dyads displayed in Table 1.

The second study we draw upon concerns analysis of APS firms' office networks as location strategies. Obviously every firm considers its products and their markets when deciding to invest the capital to set up a new office in another city. Thus, the outcome of these decisions at any one point in time constitutes a firm's location strategy. This particular geography is represented by a firm's column of integers in the service values matrix; for 2010 we have 175 such strategies. Although every strategy is different across our firms, there are some clear similarities amongst them that can be teased out using a principal components analysis. This technique is a 'data reduction' method that converts $x$ variables into $y$ components where $y$ is appreciably smaller than $x$. This is achieved by using the correlations between variables to combine them into groups of like variables, the 'principal components' of the data. The importance of each component is derived from its correlations (called loadings) with the original variables. In the analysis reported here, the 175 individual firm location strategies (variables) were reduced to just 10 components that are interpreted as common location strategies. Of these 10 components, two were interpreted as representing the core formation of economic globalization (Taylor et al. 2013b), 
and were statistically much more important than the others, between them accounting for 40 percent of the common variance found in the service values matrix. We concentrate on these two common location strategies here.

The characteristics of principal components can be discerned from their component scores on the objects of the analysis, in this case the cities. The scores for the two main components identified above, illustrating the two leading common location strategies from the 2010 service values matrix, are given in Table 2. These strategies are labeled intensive and extensive globalizations for reasons that will become apparent as we describe them. In each case we identify a 'home-region' on which the strategy is centered - most of the headquarters of the firms that constitute each component are to be found here (see Taylor et al. 2013b, Table 3) - and a 'global outreach' that identifies how the rest of the world is serviced through the location strategy. In both cases, we find the home-region encompasses U.S. cities plus London - we have coined the term USAL to describe this global-regional formation (Taylor et al. 2013b). However, although overlapping, the constitution of these two regions is quite distinctive: in the first list in Table 2 there are 12 U.S. cities plus London, in the second just three U.S. cities plus London. With global outreach, we find the obverse: just six cities in the first list but with 33 featuring in the second list. The reason for their specific labels is as follows. The intensive globalization strategy focuses on the prime locus through which economic globalization was initially constructed (USAL) with the rest of the world serviced through just three key cities in each of the two other major 'globalization arenas' - Brussels, Frankfurt and Paris in Western Europe and Hong Kong, Tokyo, and Beijing in Pacific Asia. In contrast, the extensive globalization strategy emanates from just four main USAL cities combined with a very comprehensive servicing across the rest of the world: the top five cities in the global outreach are from regions beyond USAL, Western Europe, and Pacific Asia (the latter two regions are represented, but primarily by their less important cities such as Athens and Kuala Lumpur). 
In what follows, we use results from the two globalization strategies to try and understand the findings from the previous city-dyad analysis, specifically to generalize beyond the Dubai/Frankfurt contrast.

\section{Identifying Strategic Networks and Strategic Places}

In our model, it is the firms that are the agents of globalization, the transnational network makers, and therefore to comprehend strategy, we start by identifying strategic firms and then use them to find the strategic places that are our initial concern in this article.

Although the two components are orthogonal (i.e., not related, their correlation equals 0), there will be specific firms that use elements of both common strategies as reflected in their loadings on the two components. These are the firms we will identify as 'global strategic firms'. Specifically, we use firms' component loadings on (i.e., levels of correlations with) the intensive and extensive globalization strategies to define a 'global strategic measure' for all 175 firms in our data. We compute the product of the loadings on the two components for each firm to create this measure. Global strategic firms are then identified as those with a measure of 0.10 and above. The basic reasoning behind this procedure is to find firms with relatively high positive loadings on both components. Thus, firms with a negative loading on one of the components are immediately eliminated. Firms scoring high on one component but not the other are similarly discarded: even with a rare high loading on 0.8 on a component, a firm would require a loading of at least 0.125 on the other component to reach a measure of 0.10 . In a more balanced case, a firm loading 0.33 on both components would similarly just qualify. The results of this exercise are shown in Table 3, where 25 global strategic firms are listed.

We can see from Table 3 that law is the sector with most strategic firms, nine in total which is 36 percent of law firms in the data. Management consulting with eight firms (32 percent) and advertising with five firms (20 percent) make up 
the bulk of the remaining strategic firms. In complete contrast, the category of financial services has only three of the firms listed, which is just 4 percent of financial firms in the data. There are no accounting firms at all that are identified as being strategic. The dearth of firms in these latter two sectors is consistent with the insight drawn from the APS internationalization literature reviewed earlier: the ubiquitous presence strategies of the big accounting and financial services firms result in their office networks mostly being excluded in operationalizing measurement of strategicness. In addition, geographic exclusion in this selection of firms in Table 3 is even more extreme: apart from a single London firm, all the firms are U.S. firms (i.e., in our previous parlance, they are all from USAL).

We are now in a position to identify which cities are strategic places within the world city network: we define these as cities that house offices of 10 or more of the strategic firms identified in the analytical step outlined above. This produces a list of 46 cities shown in Table $4 .^{2}$ The cities are ranked by their strategic network connectivity derived from computing the network connectivity defined by equation (2) but only including the 25 strategic firms in the calculations. Most of the cities Sassen (1991) mentions as 'global cities' appear in the top half of this table, with the cities she focuses on being ranked first (New York), second (London), and tenth (Tokyo). From our previous discussion, we can immediately note that Frankfurt (thirteenth) ranks higher than Dubai (eighteenth) supporting our preliminary suggestion that the former was more strategically placed in the world city network than the latter. We can now see that this finding is largely on account of Frankfurt attracting more strategic firms than Dubai: 20 to 15. All 25 strategic firms are found in London and New York; the latter is ranked higher because its offices tend to be more important than London's (e.g., more headquarters): this is shown by the higher connectivity New York obtains from

2 It should be noted that although this methodology includes arbitrary threshold decisions for defining strategic firms and strategic places, these were not the only ones tested in the research. The key point is that the different choices had very little effect on subsequent analysis. In other words, the results we present below are quite robust, with minor differences having no relevance to the conclusions drawn. 
its strategic firms' offices. Other cities with high connectivity per strategic firm office are Miami, just above New York, and Johannesburg and Düsseldorf, just below New York. All three of these cities are specialist regional centers with important extramural functions (e.g., continental-scale regional headquarters).

\section{Relating Strategic Network Connectivity to Global Network Connectivity}

We have regressed strategic network connectivity against global network connectivity and recorded the residuals. These are standardized ( 0 mean and a standard deviation of 1 ) so that positive numbers indicate relative strategic overconnectedness, and negative numbers indicate relative strategic underconnectedness. In Table 5, cities are ranked by size of their residuals to show the importance of their strategic connectivity relative to overall connectivity.

The follow findings from this analysis are highlighted:

- There is a clear difference between New York and London: the former is the most overconnected city relative to its global status, whereas London is actually underconnected and ranks a lowly twenty-sixth. It is unusual to show these two cities so starkly separated in studies of world or global cities.

- Other leading U.S. cities are also ranked high on this relative measure taking ranks 2 through 5. Note that this does not include Washington, DC (only ranked seventeenth), despite its importance to U.S. law firms. This confirms our measure of strategicness is more than simply reflecting the geography of law firm networks.

- But the really interesting U.S. city in this analysis is Palo Alto, CA. Ranked a lowly two hundred sixty-third in global network connectivity, it has by far the highest proportion of this connectivity that is strategic (an outlier at 16 percent, the other cities range from 7 percent to 11 percent of their 
overall connectivity being strategic). This creates a ranking of fourth in Table 5; it obviously reflects its special positionality in Silicon Valley.

- Although Chinese cities are increasingly important in terms of global network connectivity, this is not being reflected in strategicness - only Shanghai is recorded as strategically overconnected but barely so. However their respective order - Shanghai, Beijing, Hong Kong - is interesting, especially in separating Shanghai from Hong Kong.

- Among cities from other erstwhile 'third world' countries, these are generally underconnected: Buenos Aires, Delhi, Jakarta, Kuala Lumpur, Mexico City, Mumbai, and São Paulo all have large negative residuals, with the latter being the highest ranked at only thirty-first.

- The exception to the above is Johannesburg, which is highly overconnected in strategicness and is ranked eleventh overall. This presumably reflects the city's positionality with regards to extracting African raw materials.

- And finally we can note that earlier observations about the contrast between Dubai and Frankfurt are confirmed here: the former is excessively underconnected for strategicness, ranked next to last, whereas Frankfurt is strongly overconnected (ranked twelfth).

This strategic network geography that we have uncovered within the world city network is shown in Figure 1; it forms the basis of our specific interpretations of strategic places and their differences below.

\section{Interpretation of Positionalities: Disentangling NYLON and More}

The quantitative findings shown in Table 5 and represented in Figure 1 require interpretation based upon both theoretical extensions of the model employed and empirical knowledge of the cities as APS centers. In practice these two needs cannot be separated (and this is particularly the case when we try and comprehend our results on New York and London). However, in terms of the empirics, clearly we cannot deal with all 46 cities, and therefore we proceed as 
follows. We begin with consideration of London and New York, surely the world's most studied cities, and focus on writings that have discussed their differences. In addition, our interpretation takes in Castells' (1996) specification of his spaces of flows from which our model derives. We then deploy what we have learned from this prime city-dyad comparison to other specific cases. These are chosen from a mixture of intrinsic interest and availability of relevant literature to meet our needs: we present vignettes dealing with Beijing, Hong Kong and Shanghai; Palo Alto; Mexico City; Johannesburg; and conclude by returning to the contrast between Dubai and Frankfurt.

\section{London and New York}

London and New York define the only city-dyad that actually has a name: NYLON. It is part of a tradition that sees these cities at the forefront of fashion and that has been enhanced by economic globalization, whereby leading world movers and shakers are said to work through three offices, one in each city and another in transit over the Atlantic. Smith $(2012,421)$ describes how these two cities have come to be viewed as a single city: 'a transatlantic metropolis that is the heart-beat of the global economy'. The key point that Smith makes is that the cities operate in conjunction for the benefit of a small rich minority. But the conflation of the two cities hides the differences that we are seeking. Their complementarities are based upon dissimilarity, and this has been the subject of a careful comparison as global financial centers by Sassen (1999) and Wójcik (2013).

According to Sassen $(1999,81)$ New York and London constitute 'a cooperative division of labor' that operates as follows:

1. 'London is the preeminent city for global finance today, in good part due to numerous international firms that have located key operations and resources in the City [so that] London's unique denationalized platform for global operations gives it its competitive advantage' (Sassen 1999, 83-84); 
2. But 'what London lacks is Wall Street's brilliant financial engineering' and therefore 'New York dominates in another way by offering market innovations and new financial products. Wall street - still the Silicon Valley of finance - has made U.S. investment firms leaders in the global market' (Sassen 1999, 83-84).

More than a decade later it seems that this differentiation is still very much in place; Wójcik (2013), in a new survey but also drawing on Strange (1997) and Michie (2006), describes it this way:

'While New York commands access to the largest and most liquid domestic financial market in the world, London's physical, political and historical geography implies access to a different time zone, European markets, and global connections ... Taking advantage of its sheer liquid domestic market, and the deepest pool of financial engineering talent, New York leads financial innovation... Hedge funds come from the [United States], and so do venture capital and private equity. Most new products and methods of trading in the global securities markets emanated from New York.... London, in turn, has specialized as a centre, where financial firms (with US banks in the lead) adapt financial innovation from the [United States] to foreign and international markets.' (Wójcik 2013, 27412742)

The message is clear: London is particularly good for global financial business; New York is particularly good for global financial innovations.

These key differences between New York and London in the world city network can be equated with Castells $(1996,413)$ distinction between hubs and nodes in his space of flows:

'Some places are exchangers, communication hubs playing a role of coordination for the smooth interaction of all the elements integrated into the network. Other places are the nodes of the network, that is the 
location of strategically important functions that build a series of localitybased activities and organizations around a key function in the network'

In these terms, London appears more 'hub-like' through integrating business (something the reforms of Big Bang in the late 1980s were explicitly designed to facilitate), while New York is more 'node-like' in building new functions, the latter interpreted as being more strategic. Further, there is a sense in which London is 'used' with New York firms as key 'users', indicating a hierarchical element in the cities' complementarities that Sassen $(1999,81)$ recognized (see also Wall and Knaap 2011). And returning to her essential 'global city' process (Sassen 1991), where the city is both a market for and a producer of APSs, we can view the relationship between these two functions as variable across cities: high levels of new production relative to market (exchange) is a distinctive strategic place process, more focus on market service than production is a general network process. Indeed, we can see just such a distinction in the strategies of internationalizing US law firms. In the initial years at least, these firms primarily practiced U.S. (and New York specifically) law in London as part of a strategy designed to exploit the demand for advice about the structuring of financial transactions using New York law (Cullen-Mandikos and MacPherson 2002; Warf 2001). Such an interpretation provides both an explanation for our results, showing New York exhibiting more strategicness than London, and also suggests a general means of comparing cities in the world city network in terms of their relative strategicness.

\section{Beijing, Hong Kong, and Shanghai}

To illustrate the latter, we can turn briefly to the China cities in our analysis using Lai's (2012) study of the mutualities between Beijing, Hong Kong, and Shanghai as financial centers. She describes a 'dual headquarter strategy' for Beijing-Shanghai relations and 'parallel markets' for Hong Kong-Shanghai relations. Although she equates Hong Kong's role with that of New York (Lai 2012), if we move analysis from city-dyad to city-triad a rather different picture obtains. 
The roles of the three China cities are quite distinctive. Beijing is the political center, 'responsible for policy-making and macro planning' (Lai 2012, 1283), in other words, the locus of command and control. Shanghai, on the other hand, is tasked with testing new products, developing new markets and financial innovation' (Lai 2012, 1283). The result is that Shanghai has 'the highest concentration of foreign banks' and hosts 'new financial markets in futures, derivatives and foreign exchange' (Lai 2012, 1283). In contrast Hong Kong has grown as a strategic conduit 'connecting global capital and China' (Lai 2012, 1275) and continues in the role of China's 'offshore financial centre.' (Lai 2012, 1275).

It takes very little imagination to equate this structural logic to similar relations between Washington as political center, New York as innovative center, and London as offshore center. In the latter case, both London and Hong Kong have exploited a political autonomy by being outside the direct sovereign/administrative control of the United States and China, respectively. In other words, these are necessary global platforms where you can do things that are not possible in the cities of the United States and mainland China.

Our analysis adds weight to this city-triad comparison. In Table 5, the three China cities appear ranked in the same sequence as the USAL cities: New York and Shanghai are relatively most strategic, with London and Hong Kong least, and Washington and Beijing in between. London and Hong Kong, in particular, have very similar levels of relatively low strategicness.

\section{Palo Alto}

As the main city in Silicon Valley, Palo Alto is a very special strategic place, as reflected in our analysis through its unusual combination of very low general integration into the world city network with very high strategicness. How does the production of high tech innovations that Silicon Valley is famous for transfer into APS innovation as our results imply? This special place has distinctive servicing needs that have led to specialization in deal making, advising new firm start-ups and university spin-offs, arranging access to venture capital, taking 
successful firms public, plus mergers and acquisitions activity (Lashinsky 2002; Reiffenstein 2009). The main sector providing these services is law and law firms, working as 'patent attorneys' in particular and facilitating innovation exploitation. Specifically, according to Reiffenstein $(2009,572)$, law firms 'by mediating between the private interests of firms and the public concerns of the patent office, perform a critical role that is not merely ancillary but instrumental to the workings of the knowledge economy'. In other words, these law firms are part of the technology community (Reiffenstein 2009). In terms similar to those used to describe New York's role in finance, Reiffenstein quotes Friedman et al. (1989) as saying that 'the Silicon Valley lawyer not only works with engineers, he thinks of himself as a kind of engineer - a legal engineer' (Reiffenstein 2009, 578). Thus

'Silicon Valley occupies a special place in this [patent] system. Its attorneys are the "engineers" of business and legal precedent particularly as it relates to the translation of science to industry. Firms located there enjoy a locational advantage from a proximity to milieus of basic and applied research: buyers and sellers of technology' (Reiffenstein 2009, 580 ).

This special place is a strategic place because 'every one of the major Silicon Valley law offices is a component of a much larger branch network' (Reiffenstein 2009,579 ) enabling the firm 'to link buyers and sellers of technology and to lubricate the innovative process by linking places' (Reiffenstein 2009, 580), now necessarily including 'international transactions' (Lashinsky 2002). Thus, Palo Alto is only a small city, but it is a big player in the strategy of law firms and therefore the world city network as our strategicness analyses have shown.

\section{Mexico City}

Mexico City is strongly integrated into the world city network (in the top 20 listed in Table 1), but according to our analyses it is relatively underconnected strategically (Table 5). We use Parnreiter's (2010) study of how APS firms in 
Mexico City operate in global commodity chains to interpret our findings in this case.

Parnreiter (2010) begins by asking the crucial question, does the APS sector in Mexico City function as merely an enabling agent of economic globalization, or do these firms help shape the nature of the production networks they are servicing? To answer the question, he finds he has to break with Sassen's (1991, 43) 'equating the management of the world economy with its control'. These are two separate mechanisms that are 'frequently conflated' despite the fact that

'it is questionable whether all high-wage, high-tech and high-profit services necessary for running global production processes are actually related to decision-making. This question is particularly relevant to global cities in non-core countries, which have a sizeable producer service sector but are normally not considered to host decision-making capacities' (Sassen 1992, 44).

Thus, although many of the practitioners he interviewed emphasize the importance of their local office within the world city network, Parnreiter is able to show that this is largely necessary work but not strategic work. He concludes

'Though at first glance it seems that the networks of producer service firms are rather flat, their organizational model implies that there is the chain of command. Despite the fact that the local cooperation is ... seen as ... essential to do business, the "big" strategies are made by the lead partners [and] the number of lead partners an office of a global service provider can have depends ... by and large on the geography of headquarters of TNCs. Since there are far fewer companies with origins in Mexico that compete successfully in the world market than foreign firms in Mexico, the Mexico City offices of accountancy, legal or real estate firms will not often be in command' (Parnreiter 2010, 47). 
This is entirely consistent with our finding on the differences between Mexico City's global network connectivity and its strategic network connectivity. It also directly corresponds with the example presented above in our review of the APS literature in which the executive search firm Korn/Ferry uses a hybrid strategy to service Mexico City rather than the owned form used in the most strategic places.

Since Parnreiter frames his argument in world-systems terms, we are invited to extrapolate this interpretation to other important cities from 'non-core countries': from Table 5 and Figure 1 this would include São Paulo, Jakarta, Buenos Aires, Kuala Lumpur, Delhi, and Mumbai. But not all cities from non-core countries are strategically underconnected.

\section{Johannesburg}

Bangkok and Johannesburg are the exceptions to Parnreiter's argument in our analyses (Table 5 and Figure 1). In the case of the latter, we use Surborg's (2011, 325) study that employs positionality as his 'point of departure' and treats 'cities in the third world for what they are: places occupying a very specific position in the world economy, each one of them a unique place' (Surborg, 2011, 326).

Drawing on Rogerson (2005), Surborg (2011) provides hints at what is unique about Johannesburg that may have enabled it to be more strategic than expected in a world of 'uneven connections'. Put simply, in the postapartheid era, 'Johannesburg's experience was different from most other major cities in southern Africa because South Africa's liberalisation of its economy was largely a result of domestic policy, while that of other countries ... was usually the result of externally enforced structural adjustment policies' (Surborg 2011, 324). Beyond his African comparisons, we can note that this posited relative autonomy can be also contrasted with Mexico City 'trapped', as it were, in the North America Free Trade Association (NAFTA). ${ }^{3}$ Both Johannesburg and Mexico City can be

\footnotetext{
3 The fact that Toronto, the only Canadian city to be included in our 46 strategic places, is ranked bottom in Table 5 does clearly suggest that NAFTA has tended to work for the
} 
designated 'gateway cities' linking 'national "investment opportunities" to global circuits of capital' (Surborg 2011, 319) but whereas Parnreiter $(2010,50)$ concludes that Mexico City operates as 'a "bridgehead" for the interests of the dominant centres of the world economy', Johannesburg's recent trajectory may have encompassed more autonomy in the world economy for its economic elites resulting in the city's 'specific position' being more strategic in the world city network. ${ }^{4}$

A note of caution has to be inserted here. We do not have anywhere near the quality of evidence upon which Parnreiter (2010) based his Mexico City research for our understanding of Johannesburg in the world city network. The review of work on APSs also suggests that, in some cases, Johannesburg's strategicness relates to the future, exemplifying the way key cities are emerging that are at the heart of the BRICS economies (Brazil, Russia, India, China, and now South Africa). Thus, at this time, ideas about the reasons for Johannesburg's strategic positioning remain in the realm of speculation. Our findings for this city suggest further research is needed to pinpoint the mechanism attracting strategic APS firms to Johannesburg.

\section{Dubai and Frankfurt}

Finally, we return to Dubai and Frankfurt, whose alleged differences in strategicness (Table 1) first stimulated this research. The disparity between

benefit of APS firms in leading U.S. cities at the expense of their Canadian and Mexican counterparts.

${ }^{4}$ For recent examples of two of our 'strategic firms', see 'New Johannesburg Office: A Gateway to Africa for Canadian Mining Companies' at http://emailcc.com/rv/ff000884c0cfb0734ec2b80e1d49beb856820713 (accessed September 1, 2012), and see 'Bain \& Company expands Financial Services practice in South Africa' where it is announced that 'We are growing our team of financial specialists at a time of global challenges and unique opportunities for South Africa's leading players' at http://www.bain.com/about/press/press-releases/bain-andcompany-expands-financial-services-practice-in-south-africa.aspx (accessed September 1, 2012). 
these cities is a clear case of contrasting positionalities. Frankfurt's relatively high strategic importance results from its established position as Germany's leading financial center and major hub for specialist business services that has long served as the primary - though not exclusive (see Düsseldorf's and Munich's position in Table 5; Hoyler 2011) - gateway to Europe's largest economy for transnational firms, particularly those originating in the United States (Grote 2008; Hoyler, Freytag, and Mager 2008). Dubai, however, has recently been described as merely a gateway to itself (Bassens 2013). This intriguing explanation of the remarkable rise of Dubai as a 'global city' requires explication.

The residuals of our regression analysis suggest that Dubai is, indeed, one of the least strategic places in the world city network: it is ranked forty-fifth out of 46 cities. Bassens (2013) argues that the city's extensive connectivity in the office networks of APS firms does not imply that it is a global city in the full, rich sense of 'strategic sites' as put forward by Sassen (1991). Based on, inter alia, an analysis of how and why London-based financial services firms have become involved in Dubai, Bassens concludes that Dubai is, above all, seen as a site of opportunity by these firms (i.e., a market in itself for speculative surplus generation for regional and global capital):

'(T)he growth of Dubai has been mostly financed by UK investments or at least has been channeled through the UK, via a growing array of funds, asset management, banks, and other financial service firms in The City of London. Part of these investment may very well originate in the Gulf Region itself but have been recycled and re-imported in the region, a process mostly mediated by banks based in The City, which have a long business history in the Gulf.' (Bassens 2013)

Many financial services firms have an office in Dubai, which has thus become a well-connected APS cluster because it 'controls' access to its urban investment categories, which are mainly real estate markets and large infrastructure projects. Hence, Bassens (2013) suggests that Dubai should be viewed as what he calls a 'gateway global city', not to a region as Mexico City does for Mexico and 
Frankfurt does for Germany, but mainly to itself. In line with the 'strategicness' of cities for APS firms as described in our literature review, Dubai is well-connected in the office networks of APS firms, but a presence there is not strategically important.

\section{Conclusion}

This article has added to our knowledge of the contemporary world city network by going beyond the basic measurement of global network connectivities to show a distinctive pattern of strategic network connectivities. Our findings appear credible and have been shown to link with literatures on selected individual cities and with work on APSs and their strategic city location decisions and organizational forms. There are, of course, caveats to bear in mind when assessing these results overall.

- We have not produced definitive strategic places, but rather specific strategic places relating to one economic sector, APSs. We do argue the particular importance of this sector for economic globalization, but there will be other strategic places for global commodity chains defined by other criteria (Goerzen et al. 2013).

- We have provided a cross-sectional analysis for 2010 to define city positionalities, but, of course, these are inherently historical; information on city trajectories is a necessary addition to make better sense of our results.

- The latter point is very relevant to the fact we have used two U.S.-based (with London) location strategies of firms as the basis of the analysis, selected from 10 identified global location strategies. This choice was justified by their being both the most important strategies identified and because they are from the world region that largely generated economic globalization. However it is their recent history and present that are being designated 'most important'; but this designation may be less relevant for the future in a dynamic world economy: Pacific Asian, especially China, 
location strategies will have their own emerging strategic places that our methodology is not designed to find.

What we have been able to do is provide some order in an increasingly complex economy through excavating strategic places within world city network structures. In this way, we present an extensive picture in which to view the mechanisms of contemporary economic globalization.

We began with Sassen's (1991) 'global cities' as new strategic places that have solved the problem of providing operational capacity in a new global economy. Although restricting ourselves to 'spatial' identification of the strategic, this concept has still emerged as a multifarious mix of processes. In particular, our strategic places appear to have various combinations of command capacity and generation of innovations with APS firms that develop strategic presence, internationalization policies choosing to operate in these, but not other, cities to access such qualities. Strategic cities are, then, those that develop a reciprocal relationship between globally significant agglomeration and localization economies and APS firms; the latter needing to access but also helping (re)produce the former (Bathelt et al. 2004; Cook et al. 2007 Faulconbridge et al. 2011). In contrast APS firms with ubiquitous strategies maintain a presence in both strategic cities and less strategic cities that act as local market nodes. In this way we have interwoven the two key points we identified in Sheppard's (2002) geographic positionality: mutualities between the local and the nonlocal, and power relations within networks. Power in a world-city-as-strategic-place is represented overtly as command but also more covertly through innovation creating monopoly. But this power only has meaning through its deployment across networks involving other cities, both highly strategic and less so. These two features of positionality have been most clearly articulated through the contrasting interpretations of London and New York in this research.

It is, therefore, appropriate that we finish with a further comment on comparing London and New York, and we will do this by considering what spatial strategicness means for the futures of these two archetypal global cities. One 
implication of strategy is that it is long term as opposed to tactical and operational. This suggests that in the aggregate, the more strategic a place, the more resilient it should be. Translated to global cities, this means New York is likely to be more resilient than London in an increasingly dynamic world economy. But we have also disaggregated strategicness in terms of what their different levels actually mean, and this points to a quite different interpretation: the basic feature distinguishing New York's strategicness from London's is the former's leadership in service innovation. This appears to broadly work as New York generating innovations, which are then widely applied in London for global consumption. Thus, the economic success of the two global cities appears to parallel Jacobs' $(1969,39)$ 'two master economic processes': new work through innovation in city economies, and diffusion of new work by import replacement in city economies. Clearly while global city New York is a case of the former, we can add that global city London is a case of the latter. The key point is that innovation is more complex but far less common than import replacement (as simpler imitation and adaption). It might well be that if the dynamism of the world economy does precipitate a move in the center of gravity eastwards, as commonly predicted, then New York's strategic innovation character may be less resilient than London's strategic imitation character: probably new work through other's innovations (from wherever) will be easier to sustain than specific, local innovative activity itself. In this argument London can better adapt to Western relative decline as the world's most resilient global city.

\section{References}

Bagchi-Sen, S., and Sen, J. 1997. The current state of knowledge in international business in producer services. Environment and Planning A 29(7):1153-1174.

Bassens, D. 2013. The City-upon-the-Gulf: The relational growth and decline of 'world city' Dubai. In Global city challenges: Debating a concept, improving the practice, ed. M. Acuto and W. Steele, London: Palgrave. 
Bathelt H, Malmberg A, Maskell P, 2004, Clusters and knowledge: local buzz, global pipelines and the process of knowledge creation. Progress in Human Geography 28 31-56

Beaverstock, J. V. 1996. Subcontracting the accountant! Professional labour markets, migration, and organisational networks in the global accountancy industry. Environment and Planning A 28(2):303-326.

Beaverstock, J. V. 2007. Transnational work: Global professional labour markets in professional service accounting firms. In The handbook of service industries, ed. J. Bryson and P. W. Daniels, 409-431. Cheltenham: Edward Elgar.

Beyers, W. 1992. Producer services and metropolitan growth and development. In Sources of metropolitan growth, ed. E. Mills and J. McDonald, 125-146. New Brunswick, NJ: Transaction Publishers.

Bryson, J. R.; Daniels, P. W.; and Warf, B. 2004. Service worlds. London: Routledge.

Castells, M. 1996. The rise of the network society. Oxford: Blackwell.

Coe, N. M.; Johns, J.; and Ward, K. 2007. Mapping the globalization of the temporary staffing industry. The Professional Geographer 59(4):503-520.

Cook, G. A. S.; Pandit, N. R., Beaverstock, J. V.; Taylor, P. J.; and Pain, K. 2007. The role of location in knowledge creation and diffusion: evidence of centripetal and centrifugal forces in the City of London financial services agglomeration. Environment and Planning A 39(6):1325-1345.

Cullen-Mandikos, B., and MacPherson, A. 2002. US foreign direct investment in the London legal market: an empirical analysis. The Professional Geographer 54(4):491-499.

Daniels, P. W. 1993. Service industries in the world economy. Oxford: Blackwell. 
Daniels, P. W. 1995. The internationalisation of advertising services in a changing regulatory environment. The Service Industries Journal 15(3):276-294.

Dunning, J. H., and Norman, G. 1983. The theory of the multinational enterprise: an application to multinational office location. Environment and Planning A, 15(5):675-692.

Enderwick, P. 1989. Multinational service firms. Routledge Kegan \& Paul.

Faulconbridge, J. R. 2008. Managing the transnational law firm: a relational analysis of professional systems, embedded actors and time-space sensitive governance. Economic Geography 84(2):185-210.

Faulconbridge, J. R.; Beaverstock, J. V.; Nativel, C.; and Taylor, P. J. 2011. The globalization of advertising: Agencies, cities and spaces of creativity. London \& New York: Routledge.

Faulconbridge, J. R.; Engelen, E.; Hoyler, M.; and Beaverstock, J. V. 2007. Analysing the changing landscape of European financial centres: the role of financial products and the case of Amsterdam. Growth and Change 38(2):279303.

Faulconbridge, J. R.; Hall, S.; and Beaverstock, J. V. 2008. New insights into the internationalization of producer services: Organizational strategies and spatial economies for global headhunting firms. Environment and Planning A 40(1):210234.

Friedman, L. M.; Gordon, R. W.; Pirie, S.; and Whatley, E. 1989. Law, lawyers, and legal practice in Silicon Valley: a preliminary report. Indiana Law Journal 64(3):555-567. 
Goerzen, A.; Asmussen, C. G.; and Nielsen, B. B. 2013. Global cities and multinational enterprise location strategy. Journal of International Business Studies 44(5):427-450.

Grabher, G. 2001. Ecologies of creativity: the village, the group, and the heterarchic organisation of the British advertising industry. Environment and Planning A 33(2):351-374.

Grote, M. H. 2008. Foreign banks'attraction to the financial centre Frankfurt - an inverted 'U'shaped relationship. Journal of Economic Geography 8(2):239-258.

Hoyler, M. 2011. External relations of German cities through intra-firm networks - a global perspective. Raumforschung und Raumordnung 69(3):147-159.

Hoyler, M.; Freytag, T.; and Mager, C. 2008. Connecting Rhine-Main: The production of multi-scalar polycentricities through knowledge-intensive business services. Regional Studies 42(8):1095-1111.

Jacobs, J. 1969. The economy of cities. New York: Random House.

Jones, A. 2002. The global city misconceived: the myth of 'global management' in transnational service firms. Geoforum 33(3):335-350.

Lai, K. 2012. Differentiated markets: Shanghai, Beijing and Hong Kong in China's financial centre network. Urban Studies 49(6):1275-1296.

Lashinsky, A. 2002. Silicon Valley: the lawyers got screwed too. Fortune 145 (11):133-140.

Liu, X., and Derudder, D. 2012. Two-mode networks and the interlocking world city network model: A reply to Neal. Geographical Analysis 44(2):171-173. 
McNeill, D. 2008. The global architect: Firms, fame and urban form. London \& New York: Routledge.

Michie, R. C. 2006. The global securities market: A history. Oxford: Oxford University Press.

Neal, Z. P. 2008. The duality of world cities and firms: Comparing networks, hierarchies, and inequalities in the global economy. Global Networks 8(1):94115.

Parnreiter, C. 2010. Global cities in global commodity chains: exploring the role of Mexico City in the geography of global economic governance. Global Networks 10(1):35-53.

Pryke, M. 1994. Looking back on the space of a boom: (re)developing spatial matrices in the City of London. Environment and Planning A 26(2):235-264.

Reiffenstein, T. 2009. Specialization, centralization, and the distribution of patent intermediaries in the USA and Japan. Regional Studies 43(4):571-588.

Rogerson, C. M. 2005. Globalization, economic restructuring and local response in Johannesburg - the most isolated 'world city'. In Public problems - private solutions? Globalizing cities in the South, ed. K. Segbers, S. Raiser, and K. Volkmann, 17-34. Aldershot: Ashgate.

Sassen, S. 1991. The global city. Princeton, NJ: Princeton University Press.

Sassen, S. 1994. Cities in a world economy. Thousand Oaks, CA: Pine Forge Press.

Sassen, S. 1999. Global financial centers. Foreign Affairs 78:75-87.

Sassen, S. 2006. Cities in a world economy. 3rd edition. Thousand Oaks, CA: Pine Forge Press. 
Sheppard, E. 2002. The spaces and times of globalization: Place, scale, networks, and positionality. Economic Geography 78(3):307-330.

Smith, R. G. 2012. NY-LON. In International handbook of globalization and world cities, ed. B. Derudder, M. Hoyler, P. J. Taylor, and F. Witlox, 421-428. Cheltenham: Edward Elgar.

Strange, S. 1997. Casino capitalism. Manchester: Manchester University Press.

Surborg, B. 2011. World cities are just 'basing points for capital': Interacting with the world city from the global south. Urban Forum 22(4): 315-330.

Taylor, M., and Asheim, B. 2001. The concept of the firm in economic geography. Economic Geography 77(4):315-328.

Taylor, P. J. 2001. Specification of the world city network. Geographical Analysis 33(2):181-194.

Taylor, P. J. 2004. World city network: a global urban analysis. London: Routledge.

Taylor, P. J.; Hoyler, M.; and Verbruggen, R. 2010. External urban relational process: Introducing central flow theory to complement central place theory. Urban Studies 47(13):2803-2818.

Taylor, P. J.; Ni, P.; Derudder, B.; Hoyler, M.; Huang, J.; and Witlox, F., eds. 2011. Global urban analysis: A survey of cities in globalization. London: Earthscan.

Taylor, P. J.; Derudder, B.; Hoyler, M.; Ni, P.; and Witlox, F. 2013a. City-dyad analyses of China's integration into the world city network. Urban Studies doi:10.1177/0042098013494419. 
Taylor, P. J.; Derudder, B.; Hoyler, M.; and Ni, P. 2013b. New regional geographies of the world as practised by leading advanced producer service firms in 2010 . Transactions of the Institute of British Geographers 38(3):497-511.

Wall, R. S., and van der Knaap, G. A. 2011. Sectoral differentiation and network structure within contemporary worldwide corporate networks. Economic Geography 87(3):267-308.

Warf, B. 2001. Global dimensions of US legal services. The Professional Geographer, 53(3):398-406.

Wójcik, D. 2011. Securitization and its footprint: the rise of the US securities industry centres 1998-2007. Journal of Economic Geography 11(6):925-947.

Wójcik , D. 2013. The dark side of NY-LON: financial centres and the global financial crisis. Urban Studies 50(13):2736-2752.

Yeung, H. W.-C. 2005. Organizational space: a new frontier in international business strategy? Critical Perspectives on International Business 1(4):219-240. 
Table 1 Frequency of Leading Dyad Partners of the Top 20 Cities

\begin{tabular}{clc}
$\begin{array}{c}\text { Global Network } \\
\text { Connectivity } \\
\text { Rank }\end{array}$ & \multicolumn{1}{c}{ City } & $\begin{array}{c}\text { Number of } \\
\text { top } \mathbf{4 0} \text { dyad- } \\
\text { partners }\end{array}$ \\
1 & London & 9 \\
2 & New York & 10 \\
3 & Hong Kong & 8 \\
4 & Paris & 6 \\
5 & Singapore & 8 \\
6 & Tokyo & 6 \\
7 & Shanghai & 8 \\
8 & Chicago & 3 \\
9 & Dubai & 0 \\
10 & Sydney & 1 \\
11 & Milan & 0 \\
12 & Beijing & 6 \\
13 & Toronto & 0 \\
14 & São Paulo & 0 \\
15 & Madrid & 1 \\
16 & Mumbai & 0 \\
17 & Los Angeles & 4 \\
18 & Moscow & 0 \\
19 & Frankfurt & 7 \\
20 & Mexico City & 0
\end{tabular}


Table 2 Intensive and Extensive Globalization

\begin{tabular}{|c|c|c|c|}
\hline INTENSIVE & Scores & EXTENSIVE & Scores \\
\hline Home-region & \multicolumn{3}{|c|}{ Home-region } \\
\hline New York & 4.80 & New York & 2.21 \\
\hline Chicago & 4.31 & Chicago & 1.90 \\
\hline Washington & 3.86 & London & 1.59 \\
\hline London & 3.73 & San Francisco & 0.84 \\
\hline Los Angeles & 3.29 & & \\
\hline San Francisco & 2.59 & Global outreach & \\
\hline Palo Alto & 2.18 & Johannesburg & 1.51 \\
\hline Boston & 1.56 & Mexico City & 1.50 \\
\hline Philadelphia & 1.38 & Istanbul & 1.49 \\
\hline Houston & 1.36 & Sydney & 1.46 \\
\hline Dallas & 0.97 & Dubai & 1.44 \\
\hline Pittsburgh & 0.96 & Kuala Lumpur & 1.43 \\
\hline \multirow[t]{2}{*}{ Atlanta } & 0.73 & Athens & 1.42 \\
\hline & & Buenos Aires & 1.38 \\
\hline Global outreach & & Toronto & 1.26 \\
\hline Brussels & 1.48 & Copenhagen & 1.11 \\
\hline Frankfurt & 1.11 & Santiago & 1.11 \\
\hline Paris & 1.04 & Mumbai & 1.08 \\
\hline Hong Kong & 0.81 & Lima & 1.06 \\
\hline Tokyo & 0.68 & Paris & 1.06 \\
\hline \multirow[t]{19}{*}{ Beijing } & 0.68 & Manila & 1.04 \\
\hline & & Caracas & 0.99 \\
\hline & & Beirut & 0.98 \\
\hline & & Cairo & 0.94 \\
\hline & & Warsaw & 0.90 \\
\hline & & Milan & 0.90 \\
\hline & & Amsterdam & 0.90 \\
\hline & & Bucharest & 0.89 \\
\hline & & Lisbon & 0.88 \\
\hline & & Moscow & 0.87 \\
\hline & & Taipei & 0.87 \\
\hline & & Tel Aviv & 0.85 \\
\hline & & Stockholm & 0.85 \\
\hline & & Kiev & 0.81 \\
\hline & & Madrid & 0.80 \\
\hline & & Vienna & 0.75 \\
\hline & & Seoul & 0.72 \\
\hline & & Barcelona & 0.69 \\
\hline & & Jakarta & 0.68 \\
\hline
\end{tabular}

Component scores are derived from a principal components analysis in which 10 components were extracted and rotated using varimax criteria - for more details, see Taylor et al. (2013). 
Table $3 \quad$ Global Strategic Firms

APS firm
Sidley Austin
Kirkland \& Ellis
ZS Associates
Wunderman
Dewey \& LeBoeuf
A.T. Kearney
The Boston Consulting Group
McKinsey \& Company
NERA Economic Consulting
Monitor Group
DDB Worldwide
Paul, Hastings, Janofsky \& Walker
Skadden, Arps, Slate, Meagher \& Flom
McDermott Will \& Emery National
Booz \& Company
Bain \& Company
Goldman Sachs Group
Sullivan \& Cromwell
Baker \& McKenzie
L.E.K. Consulting
Saatchi and Saatchi
Morgan Stanley
TBWA Worldwide
Latham \& Watkins
Wells Fargo

\begin{tabular}{|c|c|c|}
\hline $\begin{array}{c}\text { Global } \\
\text { strategic } \\
\text { measure }\end{array}$ & Sector & Headquarters \\
\hline 0.16 & Law & Chicago \\
\hline 0.15 & Law & Chicago \\
\hline 0.15 & Management consulting & Chicago \\
\hline 0.14 & Advertising & New York \\
\hline 0.14 & Law & New York \\
\hline 0.14 & Management consulting & Chicago \\
\hline 0.13 & Management consulting & Boston \\
\hline 0.13 & Management consulting & New York \\
\hline 0.12 & Management consulting & New York \\
\hline 0.12 & Advertising & Boston \\
\hline 0.12 & Advertising & New York \\
\hline 0.12 & Law & Los Angeles \\
\hline 0.12 & Law & New York \\
\hline 0.11 & Law & Chicago \\
\hline 0.11 & Management consulting & New York \\
\hline 0.11 & Management consulting & Boston \\
\hline 0.11 & Financial & New York \\
\hline 0.11 & Law & New York \\
\hline 0.11 & Law & Chicago* \\
\hline 0.11 & Management consulting & London \\
\hline 0.11 & Advertising & New York \\
\hline 0.10 & Financial & New York \\
\hline 0.10 & Advertising & New York \\
\hline 0.10 & Law & Los Angeles* \\
\hline 0.10 & Financial & San Francisco \\
\hline
\end{tabular}

* Original (first) office, the firm claims to operate without a headquarters. 
Table $4 \quad$ Strategic Network Connectivity

\begin{tabular}{clccc} 
Rank & \multicolumn{1}{c}{ City } & $\begin{array}{c}\text { network } \\
\text { connectivity } \\
1\end{array}$ & $\begin{array}{c}\text { Number } \\
\text { of offices }\end{array}$ & $\begin{array}{c}\text { Connectivity } \\
\text { per office }\end{array}$ \\
2 & London & 10951 & 25 & 438.04 \\
3 & Chicago & 9316 & 25 & 372.64 \\
4 & Paris & 7629 & 24 & 317.88 \\
5 & Hong Kong & 6744 & 22 & 319.23 \\
6 & San Francisco & 6484 & 24 & 337.20 \\
7 & Los Angeles & 6325 & 23 & 270.17 \\
8 & Sydney & 6219 & 18 & 345.00 \\
9 & Singapore & 6126 & 17 & 360.35 \\
10 & Tokyo & 6110 & 22 & 277.73 \\
11 & Shanghai & 6019 & 23 & 261.70 \\
12 & Milan & 5731 & 19 & 301.63 \\
13 & Frankfurt & 5613 & 20 & 280.65 \\
14 & Beijing & 5581 & 22 & 253.68 \\
15 & Moscow & 5201 & 17 & 305.94 \\
16 & Miami & 5040 & 11 & 458.18 \\
17 & São Paulo & 4994 & 15 & 332.93 \\
18 & Dubai & 4937 & 15 & 329.13 \\
19 & Bangkok & 4766 & 13 & 366.62 \\
20 & Washington & 4748 & 19 & 249.89 \\
21 & Madrid & 4714 & 17 & 277.29 \\
22 & Johannesburg & 4460 & 11 & 405.45 \\
23 & Düsseldorf & 4451 & 11 & 404.64 \\
24 & Toronto & 4445 & 15 & 296.33 \\
25 & Mumbai & 4394 & 13 & 338.00 \\
26 & Mexico City & 4343 & 13 & 334.08 \\
27 & Dallas & 4327 & 12 & 360.58 \\
28 & Buenos Aires & 4132 & 12 & 344.33 \\
29 & Amsterdam & 4128 & 11 & 375.27 \\
30 & Jakarta & 4118 & 11 & 374.36 \\
31 & Stockholm & 4079 & 12 & 339.92 \\
32 & Melbourne & 4061 & 14 & 290.07 \\
33 & Seoul & 4052 & 13 & 311.69 \\
34 & Kuala Lumpur & 4035 & 10 & 403.50 \\
35 & Munich & 4002 & 15 & 266.80 \\
36 & Auckland & 3952 & 10 & 395.20 \\
37 & Brussels & 3846 & 14 & 274.71 \\
38 & Taipei & 3790 & 11 & 344.55 \\
39 & Boston & 3712 & 14 & 265.14 \\
40 & Warsaw & 3630 & 10 & 363.00 \\
41 & Zurich & 3562 & 12 & 296.83 \\
42 & Riyadh & 3547 & 12 & 295.58 \\
43 & Rome & 3475 & 13 & 267.31 \\
44 & Delhi & 3412 & 12 & 284.33 \\
45 & Houston & 3255 & 13 & 250.38 \\
46 & Palo Alto & 2385 & 12 & 198.75 \\
& & & &
\end{tabular}


Table $5 \quad$ Residuals from Regressing Strategic Network Connectivity against Global Network Connectivity

\begin{tabular}{|c|c|c|}
\hline Rank & City & Residual \\
\hline 1 & New York & 2.53 \\
\hline 2 & San Francisco & 2.36 \\
\hline 3 & Chicago & 2.26 \\
\hline 4 & Palo Alto & 1.51 \\
\hline 5 & Los Angeles & 1.36 \\
\hline 6 & Bangkok & 0.98 \\
\hline 7 & Auckland & 0.93 \\
\hline 8 & Düsseldorf & 0.92 \\
\hline 9 & Miami & 0.79 \\
\hline 10 & Riyadh & 0.78 \\
\hline 11 & Johannesburg & 0.74 \\
\hline 12 & Frankfurt & 0.74 \\
\hline 13 & Paris & 0.63 \\
\hline 14 & Stockholm & 0.48 \\
\hline 15 & Sydney & 0.47 \\
\hline 16 & Dallas & 0.26 \\
\hline 17 & Washington & 0.24 \\
\hline 18 & Milan & 0.11 \\
\hline 19 & Shanghai & 0.01 \\
\hline 20 & Tokyo & 0.00 \\
\hline 21 & Moscow & -0.01 \\
\hline 22 & Beijing & -0.02 \\
\hline 23 & Rome & -0.26 \\
\hline 24 & Munich & -0.27 \\
\hline 25 & Taipei & -0.29 \\
\hline 26 & London & -0.31 \\
\hline 27 & Hong Kong & -0.32 \\
\hline 28 & Melbourne & -0.40 \\
\hline 29 & Houston & -0.43 \\
\hline 30 & Singapore & -0.45 \\
\hline 31 & São Paulo & -0.47 \\
\hline 32 & Boston & -0.58 \\
\hline 33 & Warsaw & -0.67 \\
\hline 34 & Jakarta & -0.76 \\
\hline 35 & Madrid & -0.77 \\
\hline 36 & Buenos Aires & -0.90 \\
\hline 37 & Mexico City & -0.92 \\
\hline 38 & Zurich & -0.95 \\
\hline 39 & Seoul & -0.96 \\
\hline 40 & Kuala Lumpur & -0.99 \\
\hline 41 & Amsterdam & -1.12 \\
\hline
\end{tabular}


$-1.13$

43

Mumbai

$-1.18$

$44 \quad$ Brussels

$-1.22$

45

Dubai

$-1.24$

46

Toronto

$-1.50$ 
Figure 1 The strategicness of major cities in the world city network

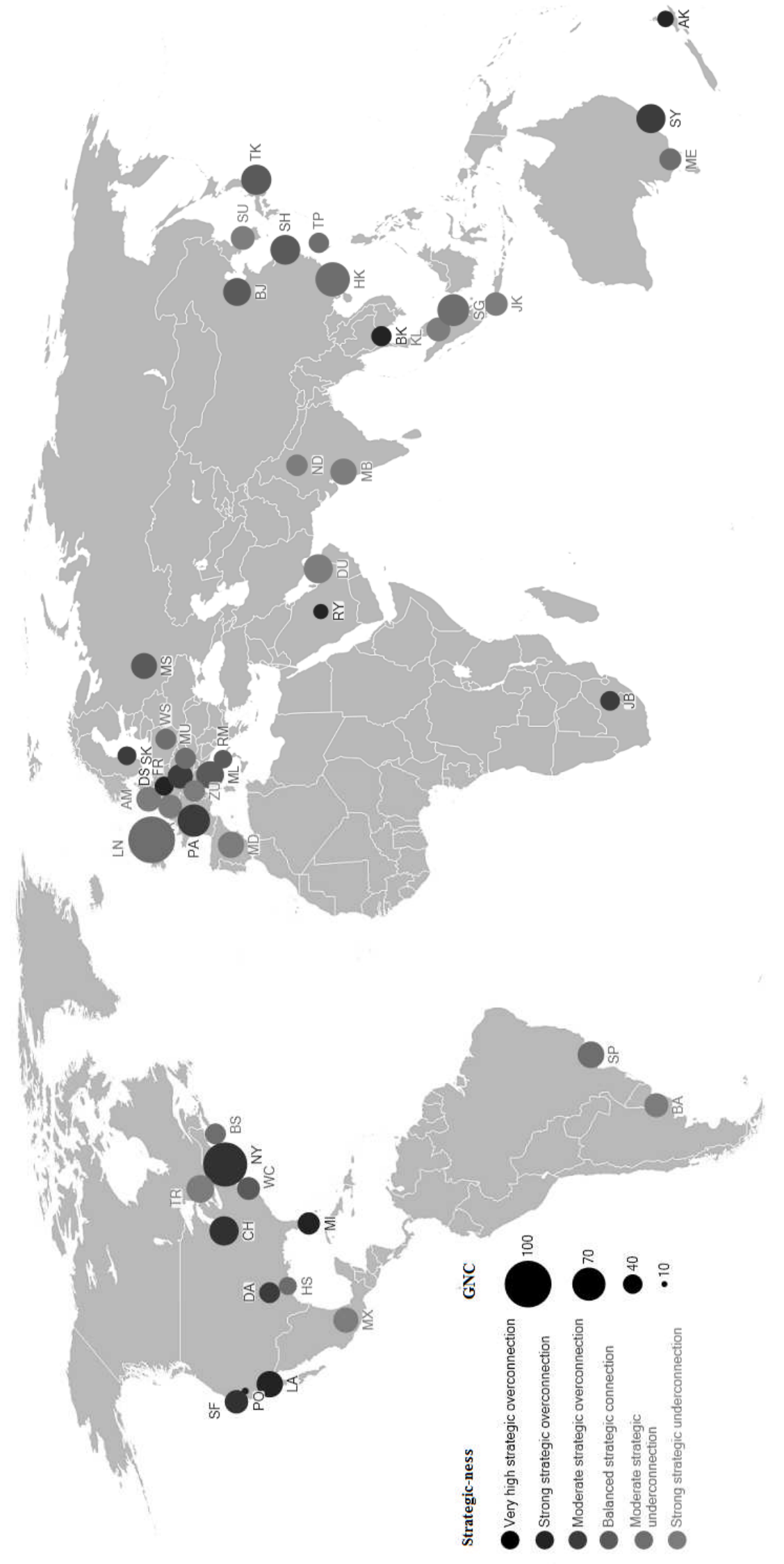

